ББК 28.04

\title{
BIOPOLYMERS FOR APPLICATION IN PHOTONICS
}

\author{
Rau Ileana
}

$\mathrm{PhD}$, Professor, Faculty of Applied Chemistry and Materials Science, University Politehnica of Bucharest relatii.publice@upb.ro Polizu St., 1-7, 011061 Bucharest, Romania

\section{Kajzar Francois}

$\mathrm{PhD}$, Professor, Faculty of Applied Chemistry and Materials Science, University Politehnica Bucharest, relatii.publice@upb.ro Polizu St., 1-7, 011061 Bucharest, Romania

\begin{abstract}
The possibilities of utilization of biopolymers, the deoxyribonucleic acid (DNA) in particular, are reviewed and discussed. The ways of their functionalization with photoresponsive molecules to get desired properties are described and illustrated on several examples as well as the processing of materials into thin films. Their room- and photo-thermal stability, studied by spectroscopic techniques is reported, together with optical damage thresholds. Physical properties, and more particularly linear, nonlinear and photo-luminescent properties of obtained materials are also reviewed and discussed.

Key words: deoxyribonucleic acid, collagen, linear optical properties, photoluminescence, photo-thermal stability, optical damage threshold, thin films.
\end{abstract}

\section{Introduction}

During last 30 years the synthetic polymers have found large applications in almost each domain of human activity, and particularly in construction, car industry, medicine, textile and $\checkmark$ more recently in advanced technologies. These के polymers are obtained principally from coal and if from oil by chemical transformation and है synthesis. However, due to the fact that the coal I. and oil resources are limited, on one hand, and - contribute to an important pollution of the planet, 클 on the other hand, the scientists turn their (a) attention to the nature of produced biopolymers.
Indeed, the decay time for a thin foil of polyethylene (PET), used largely in fabrication of plastic bottles, is 5-10 years. Also the largely used polystyrene (PS) decomposes in 50 years, low-density polyethylene (LDPE) in 5001000 years. Polypropylene (PP), used in clothing and rope fabrication, practically does not degrade [53]. The fabrication of some polymers, like polyvinyl chloride (PVC), used largely in construction and in fabrication of toys is done with the use of toxic dioxin. Its degradation is associated with the production of unhealthy subproducts. These facts explain well the already mentioned switch of the scientists 


\section{ТЕХНИКО-ТЕХНОЛОГИЧЕСКИЕ ИННОВАЦИИ}

interest to natural biopolymers, originating from renewable and biodegradable resources.

One of these polymers which attracted recently some interest is chitosan which is a polysaccharide, occurring in the exoskeleton of invertebrates and in their internal structures. It was shown that it has some interesting optical properties $[2 ; 48]$. There are two biopolymers produced in a very large amount by nature which are the deoxyribonucleic acid (DNA) and collagen. Both are biodegradable, abundant and can be obtained from, e.g., the waste of food producing industry.

DNA, also called the "molecule of life", is present in all living species, being responsible for its development and heritage not only of humans and animals but also of the vegetables. Since the discovery of its molecular structure by Watson and Crick [14; 56] (Figure 1) in 1953 the deoxyribonucleic acid (DNA) attracted a lot of interest of biologists, chemists, and later, of physicists. Indeed, this supramolecule exhibits a peculiar double helix structure, consisting of stacked base pairs of molecules arranged as rungs of the ladder. The pairs consist always of adenine with thymine and of guanine with cytosine
(Figure 2). The two helix backbones are made of sugar and phosphate groups, joined internally by the ester bonds. The base pairs are linked together by the strong hydrogen bonds (Figure 3). As the outside groups are phosphates, the DNA macromolecule presents a net negative charge, compensated by sodium ions, which are nonlocalized counter ions. They can move freely along the macromolecular chain surface [29].

As it was found originally by X-Ray studies by Watson and Crick the pitch of the helix is of $3.4 \mathrm{~nm}$, its diameter of $1 \mathrm{~nm}$ respectively and the distance between two neighbouring nucleotides of $0.34 \mathrm{~nm}$ (Figure 1). In solution these dimensions may be a little different as reported by Mandelkern et al [28], ranging from 2.2 to $2.6 \mathrm{~nm}$ for the helix radius, $3.3 \mathrm{~nm}$ for the pitch, and $0.34 \mathrm{~nm}$ for the distance between two nucleotides.

The double-stranded helix form major and minor grooves, wide, respectively, of $2.2 \mathrm{~nm}$ and $1.2 \mathrm{~nm}$ [13]. Their presence is important for the functionalization of DNA as it will be discussed later.

The size of DNA depends on the level of development of a given species. Usually it is expressed in the number of base pairs (bp) and spans from several tens of bp, as for Escherichia

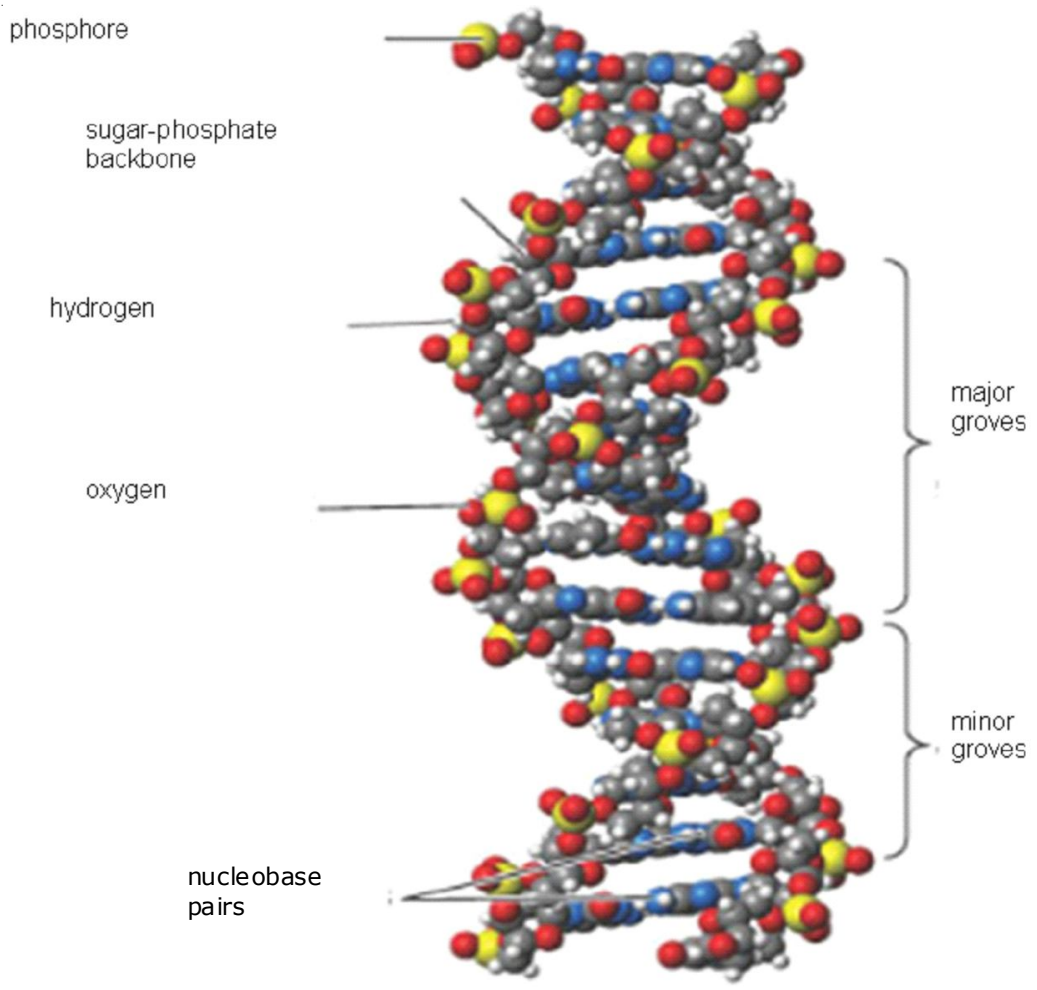

Fig. 1. Chemical structure of a segment of DNA molecule (adapted from [37]). 


\section{ТЕХНИКО-ТЕХНОЛОГИЧЕСКИЕ ИННОВАЦИИ}

coli bacteria (76 bp), to $3000 \mathrm{Mbp}$ for Human DNA. There exist a lot of programs available on Internet which transform the base pairs number into molecular mass (Daltons). A base pair has molecular mass of about $660 \mathrm{Da}$.

One of the important arguments used in favour of biopolymers for replacing the synthetic polymers in photonics and in electronics, and particularly by DNA, is its abundance and renewability. DNA is usually obtained from the waste produced by food processing industry. Thus it can be cheap. In contrary to synthetic polymers, if not protected, biopolymers are biodegradable. Thus, their use should permit to decrease the pollution by slowly decomposing synthetic polymers. This, is comforted by the present scientific policy related to the humanity problem of creating a sustainable society with durable development, disposing renewable resources and minimising the environment pollution.

Besides, the above mentioned advantages, there are other important properties of DNA, which are in favour of it in photonics and in electronics, as it will be shown and discussed later in this paper. It concerns, in particular, the versatility, thin film processability and the possibility of tailoring optical and electrical properties by DNA functionalization. Its specific double-strand helical structure, with minor and<smiles>Nc1ncnc2[nH]cnc12</smiles>

Adenine (A)<smiles>Nc1cc[nH]c(=O)n1</smiles>

Cytosine (C)<smiles>Nc1nc2[nH]c(=O)[nH]c2c(=O)[nH]1</smiles>

Guanine (G)<smiles>Cc1c[nH]c(=O)[nH]c1=O</smiles>

Thymine (T)

Fig. 2. Chemical structure of four nucleobases

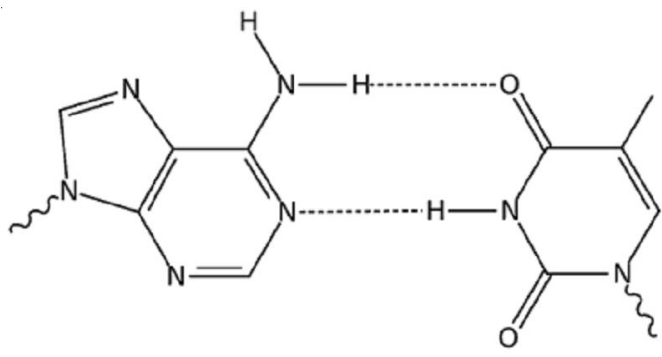

Adenine
Thymine

$a$

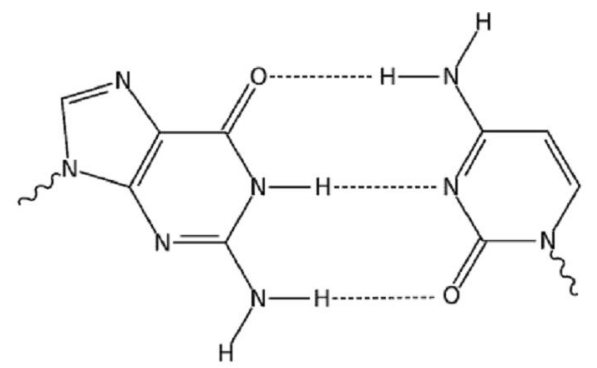

Guanine
Cytosine

$b$

Fig. 3. Nucleobase pairs:

Adenine - Thymine $(a)$ and Guanine - Cytosine $(b)$ and the hydrogen bonds between the nucleotides 
major groves, provides a large free volume for doping molecules as well as a good protection against photo thermal degradation.

Another potentially very interesting biopolymer is collagen. Its name originates from Greek word kola meaning 'glue'. It was indeed used as glue in antic times. This biopolymer is the most abundant in human and animal organisms supramolecule, making $c a 25 \%$ of all their proteins, i.e. $5 \%$ of their mass. It plays an important role in assuring connectivity of mammals tissues and in their structuring. Its molecular mass is of $c a 325000 \mathrm{Da}$. A collagen fiber with $1 \mathrm{~mm}$ diameter may withstand a $10 \mathrm{~kg}$ load.

The collagen molecule is composed of three associated alpha polypeptide chains, as shown in Figure 4, linked by hydrogen bonds between hydroxylysine and l'hydroxyproline and by covalent bonds. An alpha chain is constituted of 1055 amino acids. They may combine in different ways and form a large variety of different collagens. Each of them is characterized by an appropriate structure and exerts a particular role in a given organ. For example collagen I is present in cornea, skin and bones while collagen III can be found in the cardiovascular system.

The building unit of collagen is the tropocollagen. It is a noncentrosymmetric molecule, exhibiting second harmonic generation as observed by several research groups. The length of tropocollagen is of $c a 280 \mathrm{~nm}$ and the diameter of $1.5 \mathrm{~nm}$, respectively. The already mentioned constituent elements amino acids comprise glycine, proline, hydroxylysine and 4-hydroxyproline (Figure 4). There are several types of molecular chains, which are composed of repetitive sequences of these amino acids. Glycine is repeated throughout the molecule. The carbohydrates are attached to hydroxylysine. The cohesion of tropocollagen is ensured by strong hydrogen bonds between glycine and hydroxyproline (Figure 4).

The deoxyribonucleic acid exhibits little $\pi$ electron conjugation which is interesting for application in photonics. It is mainly to the presence of double $\mathrm{C}=\mathrm{C}$ bands, in nucleobases. Such

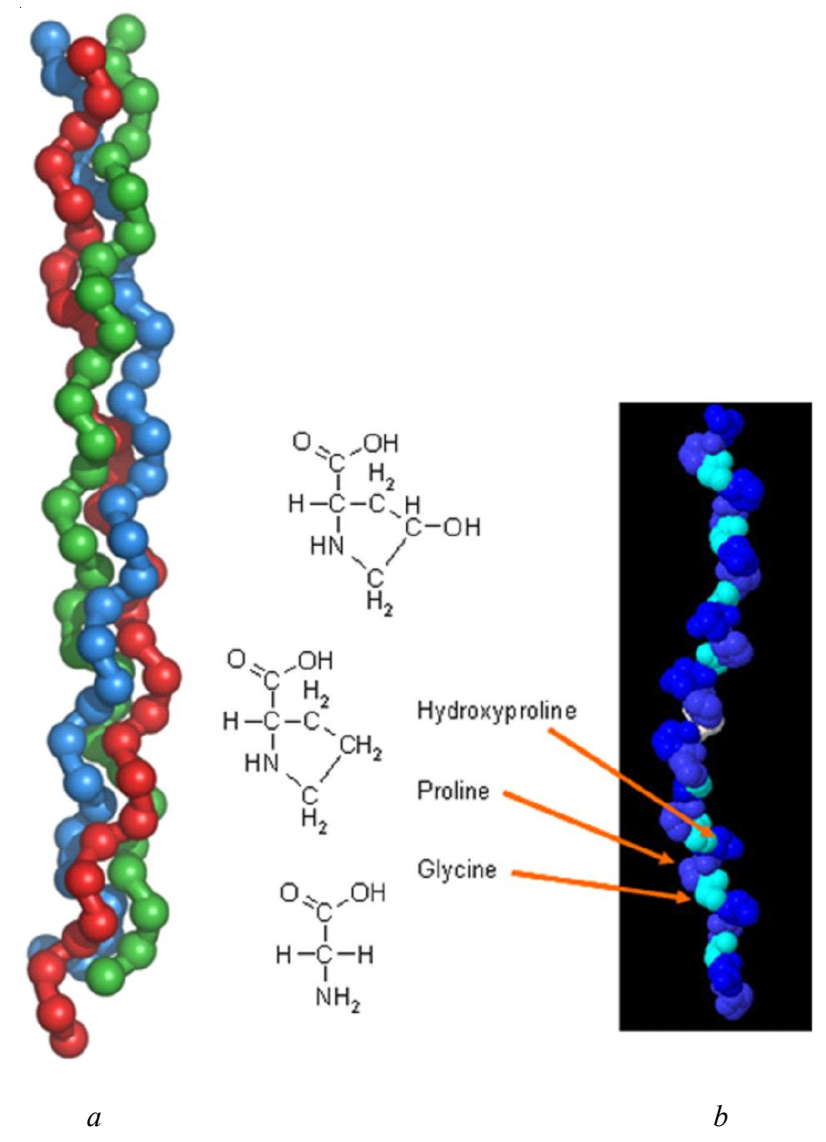

Fig. 4. Chemical structure of collagen ( $a$ ) and tropocollagen (b) 
conjugation is absent in collagen. Therefore to obtain desired properties is necessary for practical applications of both biopolymers.

In this Chapter we review and discuss the results of our recent studies on functionalization, photo-thermal stability of collagen and DNA and collagen-based complexes, together with stability in high intensity laser beams. Some properties of obtained complexes as well as their practical applications are also reviewed and discussed.

\section{Materials}

The deoxyribonucleic acid we are using in our studies, was purchased at Ogata Photonics Laboratory, Chitose, Hokkaido, Japan. It is obtained from the waste produced in salmon processing [16; 53], particularly, from roe and milt. The DNA extraction process is shown schematically in Figure 5. Frozen roe and milt are first grinded. Then the grinded product is homogenized. Then starts the important and difficult process of protein elimination. The homogenized product is treated with enzymes DNA, dissolved in water and decolorized with active carbon. Finally, the product is filtered and freeze-dried. The most delicate and difficult step in purification process is the separation of proteins. The final product contains usually $c a 98 \%$ of DNA and $c a 2 \%$ of proteins [53].

Collagen is also obtained from the waste produced in meat processing. It is usually obtained from skin and bones of animals, principally such as beefs and porks as well as from fish [47; 52]. The collagen used in our study was obtained at University Politehnica of Bucharest from beef skin using an original procedure described in Refs. $[1 ; 46]$. DNA is known to denature at around $90{ }^{\circ} \mathrm{C}$, changing its helical structure from doublestranded to single-stranded [39; 49], limiting in this way the temperature range of applicability. Also thin film processing and water solubility only limits the possible range of its applications.

Collagen can be irreversibly hydrolyzed giving gelatin, which is largely used in food industry.

\section{Functionalization}

As already mentioned, pure DNA and collagen represent a limited interest for applications in photonics. They exhibit low $\pi$ electron conjugation, which is principally present in DNA only owing to the $-\mathrm{C}=\mathrm{C}$ - conjugated bonds in nucleobases.

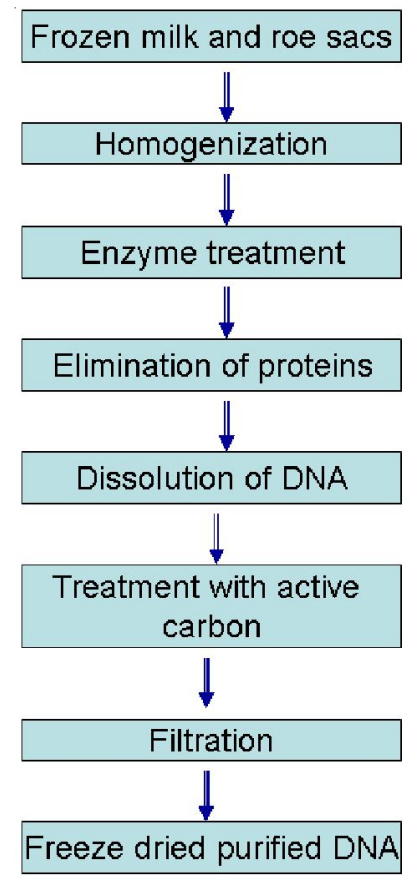

Fig. 5. Successive steps in obtaining pure DNA from the salmon processing waste 


\section{ТЕХНИКО-ТЕХНОЛОГИЧЕСКИЕ ИННОВАЦИИ}

Pure DNA has a limited potential for applications in photonics. This biopolymer is soluble in water only, a solvent which doesn't belong to the preferred ones in the device fabrication technologies, although some electronic devices containing water were already described $[18 ; 32]$. Also a weak $\pi$ electron conjugation, only in phenyl rings, provides limited hyperpolarizabilities to this compound. Therefore the only possible practical use of this biopolymer in photonics is as an optically inactive material, except if its chirality can be exploited in some ways.

DNA is an anionic polyelectrolyte [26;27] with $\mathrm{Na}^{+}$ion being a counterion. Therefore the first possible approach to functionalize is through the electrostatic interaction by substituting $\mathrm{Na}^{+}$by a positively charged molecule, which will be bond to the DNA helix by the electrostatic force, changing in this way its properties. Several approaches were done in this direction. A significant DNA material improvement was obtained by functionalizing it chemically with ionic liquids, as shown by Iijiro \& Okahata [21], Okahata [19;45], Serguev et al [41],
Kimura et al [24], and more particularly by Ogata and coworkers from Chitose Institute of Technology [22; 23; 25; 54; 55; 57]. They have shown that the counterion $\mathrm{Na}^{+}$can be substituted by an amphiphilic cation, leading to a more stable compound, soluble in polar organic solvents and generally insoluble in water. They used several cationic surfactants which react with DNA via electrostatic forces and they succeeded in making several stable complexes using surfactants such as: cetyltrimethylammonium (CTMA) (Wang et al [55] and an aromatic one the benzyldimethylammonium (CBDA) [ibid.] Watanyuki), whose chemical structures are shown in Figure 6. Recently some other surfactants were proposed, such as aromatic ones: benzalkonium chloride (BA), and a linear amphiphilic one didecyldimethyl ammonium chloride (DDCA), whose chemical structures are also shown in Figure 6. The complexes formed with the new surfactants are soluble in a larger number of solvents making possible DNA functionalization with a greater class of molecules.

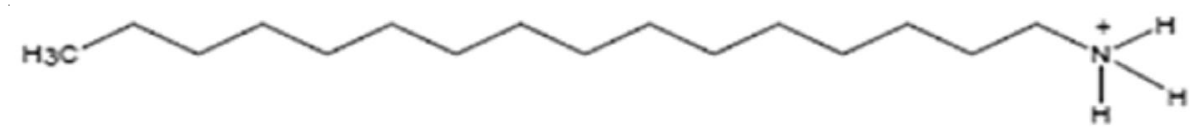

cetyltrimethrlammonium (CTMA)

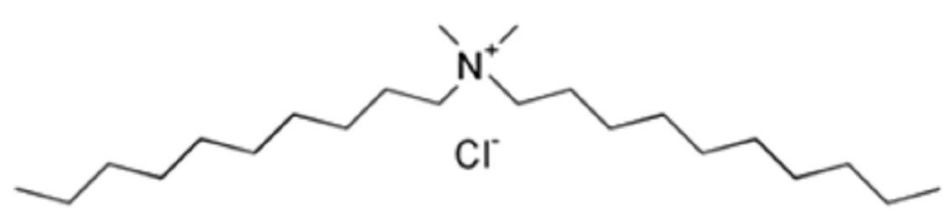

didecyldimethyl ammonium chlonide (DDCA)

$a$

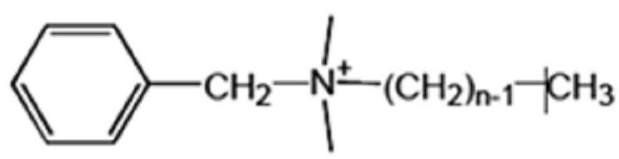

benzyldimethylamamonium (CBDA).

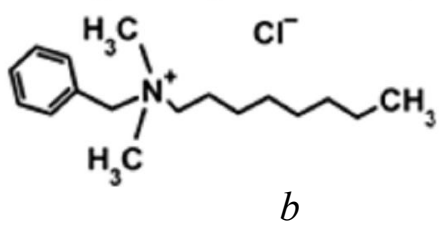

Fig. 6. Chemical structures of several linear amphiphilic (a) and aromatic $(b)$ surfactants 


\section{ТЕХНИКО-ТЕХНОЛОГИЧЕСКИЕ ИННОВАЦИИ}

Figure 7 shows schematically the reaction of a surfactant (with a counterion, usually $\mathrm{Cl}^{-}$or $\mathrm{ClO}_{4}^{-}$) with DNA (counterion $\mathrm{Na}^{+}$). As result of this reaction a stable DNA-surfactant complex is formed, which precipitates in reaction solvent (water) and can be easily recovered. The resulting sodium ion form a salt with the surfactant counterion which remains in water. The DNA surfactant complexes are stable. Their thermal degradation takes place at around $230{ }^{\circ} \mathrm{C}[3$; $20 ; 31]$.

As already mentioned, DNA undergoes a denaturation process when heated to $90{ }^{\circ} \mathrm{C}$. It consists in transformation from double-strand to single-strand helix. In contrary, the DNA surfactant complex shows a better stability, maintaining its double stranded helical structure to temperatures overpassing $100{ }^{\circ} \mathrm{C}[16]$, what is sufficient for majority of practical applications.

Functionalization of DNA with the above cited surfactants does not provide them the required in photonics photosensitivity, as the used molecules also show a little (aromatic surfactants) or none (amphiphilic surfactants) $\pi$ electron delocalization. Figure 7 compares optical absorption spectra of thin films of DNA with those made of two complexes: all show absorptions around $260 \mathrm{~nm}$, which are due to conjugated $\pi$ electrons of nucleobases and of phenyl ring in the case of aromatic surfactants. Therefore it is necessary to functionalize the biopolymer or its complex with a surfactant with a photosinsitive molecule. This can be done in three different ways:

(i). intercalation,

(ii). random doping, as in the case of synthetic polymers,

(iii) doping through molecules inclusion in minor or major groves,

(iv). covalent attachement to DNA chains.

Intercalation consists on introduction of a doping molecule between nucleobase pairs stacks, as shown in Figure 8 (a). As the space is limited, only small, ring-type, flat molecules can intercalate. A large $\pi$ electron overlap between the doping molecules and the nucleobase pairs is expected in this case.

Recently Pawlik et al [34] (see also Refs. $[35 ; 36])$ have proposed another intercalation mechanism for DNA-surfactant complexes they proposed to call "semi-intercalation". In that case

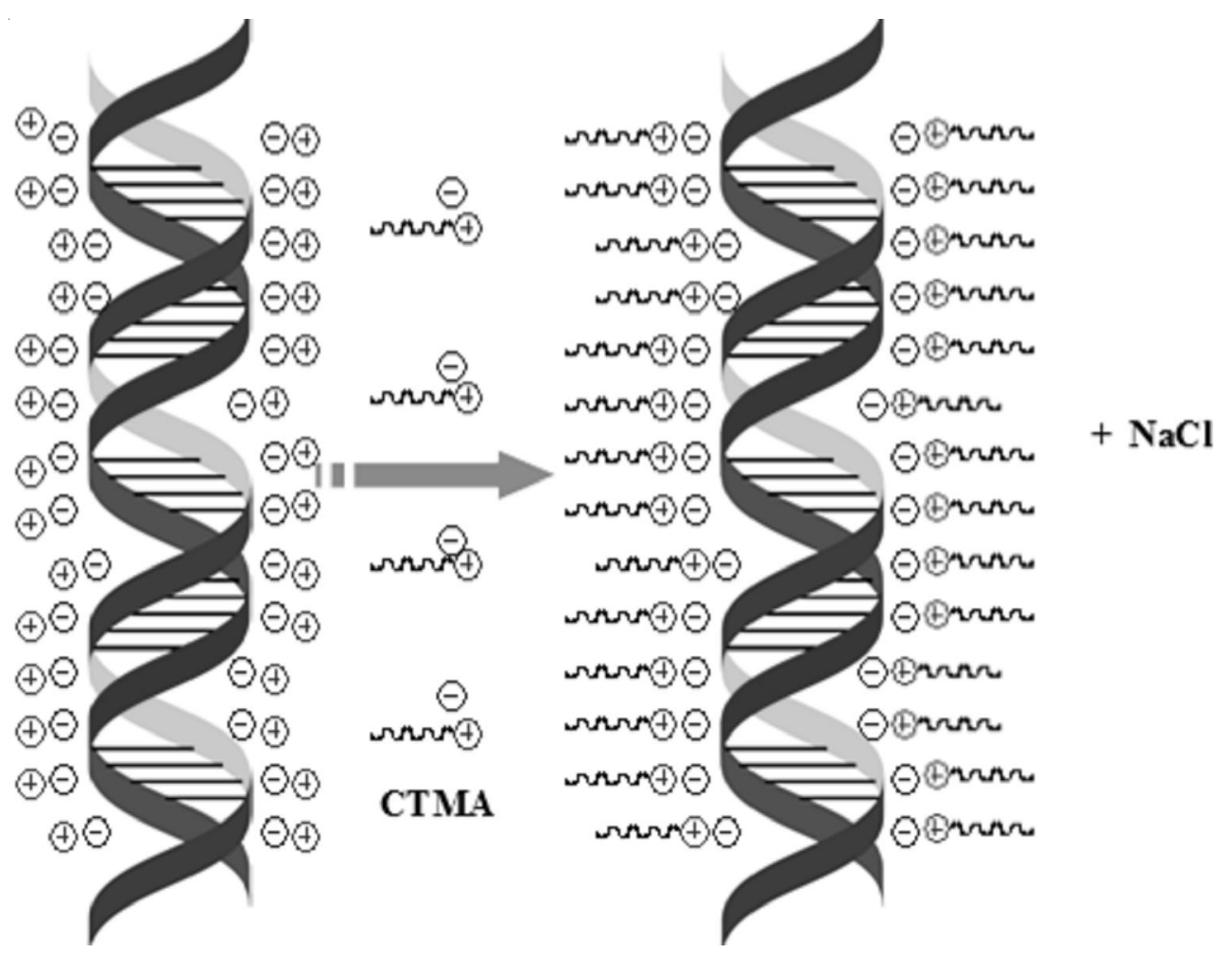

Fig. 7. Electrostatic interaction between DNA and surfactant leading to the formation of a stable complex (courtesy of J.G. Grote, UA Air Force Wright Patterson Research Labs, Dayton, OH, USA) 


\section{ТЕХНИКО-ТЕХНОЛОГИЧЕСКИЕ ИННОВАЦИИ}

the doping molecules are partly inserted between the surfactant molecules, as shown in Figure 9 for DR1 in DNA-CTMA matrix. Thus, the dopants do not bind directly to the DNA backbone but are separated from, keeping in this way a larger conformational mobility. The Monte Carlo simulation calculations performed using this model allowed to explain the photochromic properties of DNACTMA-DR 1 complex. They reproduced accurately the main experimental results of laser dynamic inscription of diffraction gratings in this photochromic material: short response time, low diffraction efficiency, single-exponential kinetics and flat wavelength dependence. It allowed also to explain also the origin of memory effect upon light excitation observed in DNA-CTMA-DR1 complexes.

The simplest way of DNA or DNAsurfactant functionalization is by making solid solutions, as it is frequently done with synthetic polymers, and as it was proposed originally by Havinga and Pelt [17] to improve electroluminescent properties of some organic dyes. This is done in solution, while existence of a common solvent is required. It is difficult to be

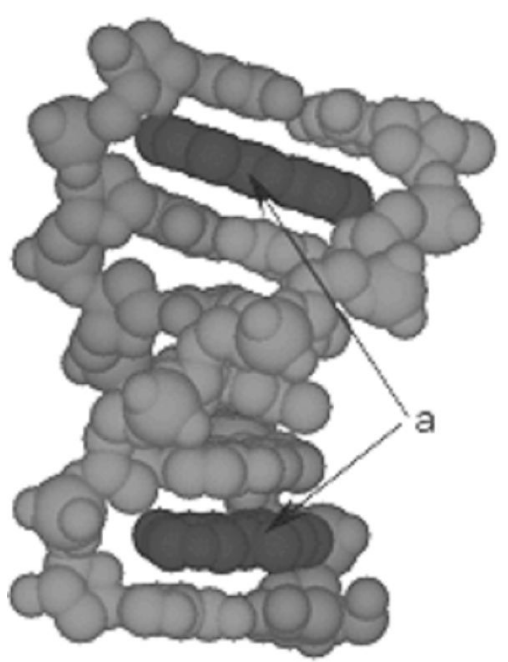

Intercalation

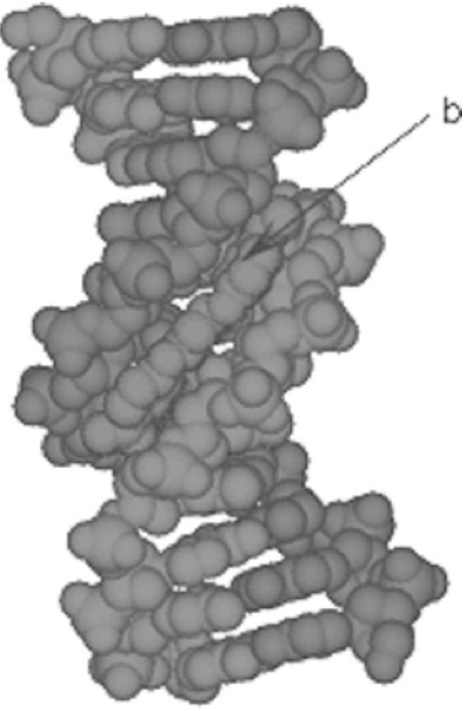

Groove binding

Fig. 8. Intercalation $(a)$ and groove binding $(b)$ of chromophores in DNA

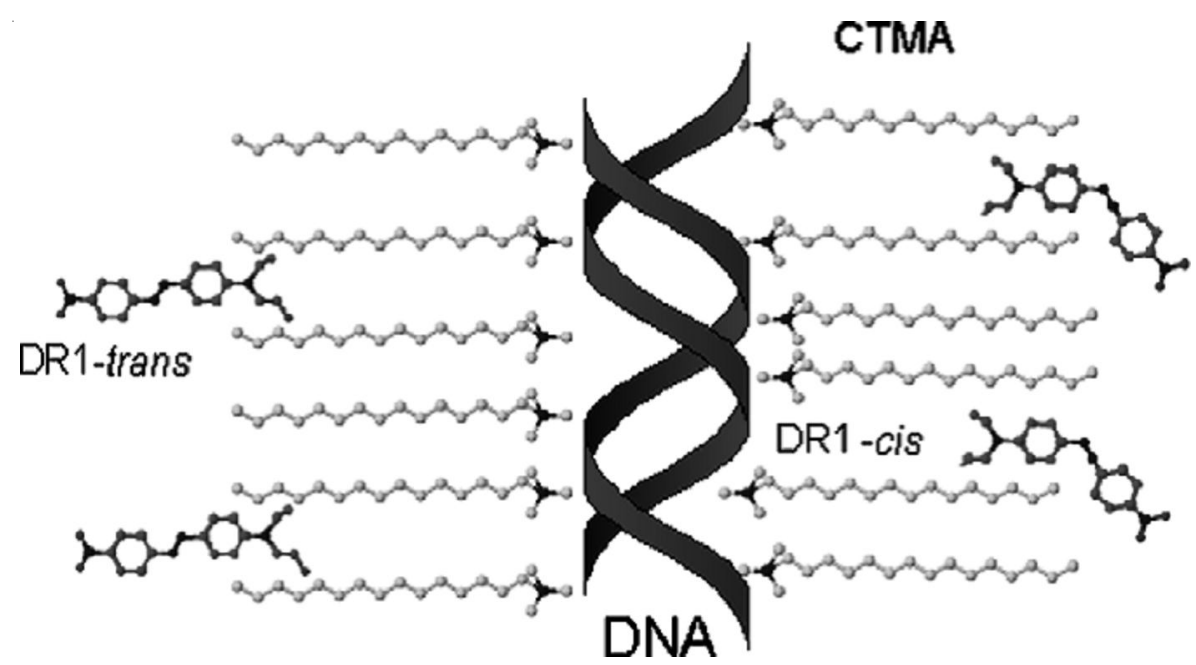

Fig. 9. Illustration of the semi-intercalation in cis and trans forms of DR1 molecule embedded in DNA-CTMA complex [34] 


\section{ТЕХНИКО-ТЕХНОЛОГИЧЕСКИЕ ИННОВАЦИИ}

done with DNA and collagen as these biopolymers are soluble in water only. The DNA-surfactant complexes are insoluble in water and soluble, depending on surfactant used, in a large variety of solvents. Indeed, lots of different complexes, particularly DNA-surfactant-photosensitive chromophore complexes were successfully made in this way [see e.g. Grote [16], Rau et al [38], Derkowska et al [15]). Photos of some examples of solutions of photosensitive chromophores are reported in Figure 10, $a$.

Some, particularly linear molecules, like so called Hoechst molecule 33258 (Figure 11, a) fits into the minor or major groves of DNA (Figure 9), without a Van der Walls contact. This type of molecules, if showing photoluminescence, is used to stain DNA, are important and find large practical applications, particularly in criminology.

There are several attempts to attach covalently the photosensitive molecules to DNA by using different synthetic methodologies. In particular, a lot of efforts was done with planar molecules, such as porphyrins through a direct modification of nucleobases [10] or using acyclic linkers [33]. Attempts were also done in replacing nucleobases in the middle of the helix
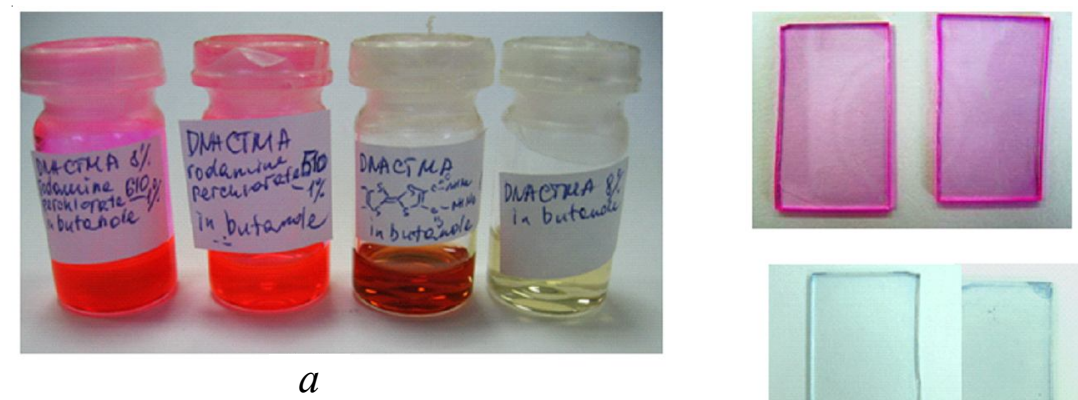

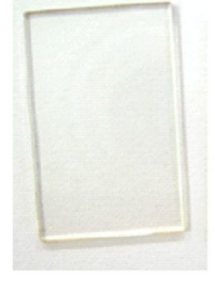

$b$
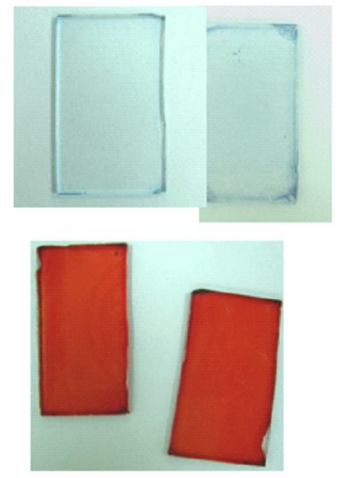

c

Fig. 10. Photos of solutions in DNA-CTMA matrix (from left to right: first two Rhodamine 610, next - TTF molecule, the last - undoped DNA-CTMA $(a)$, thin films of DNA-CTMA $(b)$ and thin films DNA-CTMA

chromophore complexes: from bottom: Rhodamine 590, Nile Blue and Disperse Red 1, respectively $(c)$

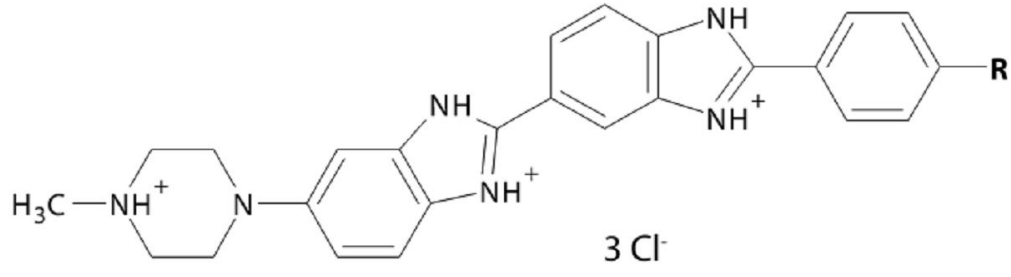

$a$

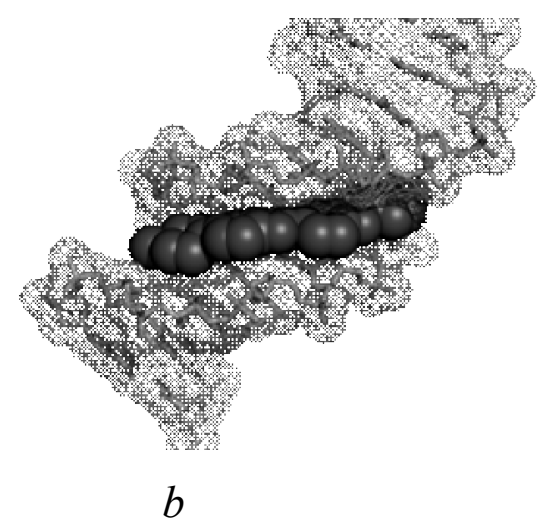

$b$

Fig. 11. Chemical structure of Hoechst molecule $33258\left(\mathrm{C}_{25} \mathrm{H}_{26} \mathrm{~N}_{6} \mathrm{R}\right)$ chloride $(a)$ and its binding to the minor grove of DNA $(b)$ 


\section{ТЕХНИКО-ТЕХНОЛОГИЧЕСКИЕ ИННОВАЦИИ}

by porphyrin molecules [9] for solar energy conversion $[11 ; 12]$ as well as in photodynamic therapy applications [30].

Recently Stephenson et al $[43 ; 44]$ reported the synthesis of $\beta$-pyrrolic-functionalised porphyrins and their covalent attachment to 2'deoxyuridine and DNA. The authors observed a better thermal stabilisation of parallel porphyrinmodified triplex-forming oligonucleotide strands, while the anti-parallel duplexes were destabilised.

\section{Conclusions}

In this Chapter we review and discuss the recent work on two biopolymers: collagen and deoxyribonucleic acid in view of their application in photonics. Both are abundant, renewable, biodegradable and nature-fabricated macromolecules. They can be obtained from the waste produced in food processing industry. That used in our studies originates from the waste produced in salmon processing industry. Thus, they can be cheap and the renewable resources are practically unlimited. It can be used, at least, partly, to replace synthetic polymers as matrix for photosensitive molecules, offering an interesting, ecologically friendly, alternative material for applications in photonics and in electronics.

Owing to its peculiar double-stranded helical structure DNA offers more than synthetic polymers. Particularly there is a larger free volume offering faster conformational processes, as discussed here, and at the same time a better stability of embedded molecules. Indeed, as shown by the described and discussed here, the recent photothermal degradation studies performed on a series of DNA-based complexes significantly larger first order decay constants for several chromophores embedded in collagen or DNA matrices than when these molecules are dissolved in the commonly used synthetic polymers like the polymethyl methacrylate (PMMA). Also, DNA exhibits a higher optical damage threshold.

Acknowledgements. The authors acknowledge the financial support of Romanian Ministry of Education, Research, Youth and Sports, through the UEFISCDI Body, under Contract Number 279/7.10.2011, Code Project PN-II-ID-PCE-2011-3-0505.

\section{REFERENCES}

1. Albu M.G. Collagen gels and matrices for biomedical applications. Pignatello R., ed. Biomaterials Applications for Nanomedicine. Lambert Academic Publishing, Saarbrücken, 2011.

2. Azofeifa D.E., Arguedas H.J., Vargas W.E. Optical Properties of Chitin and Chitosan Biopolymers With Application to Structural Color Analysis. Opt. Mat., 2012, vol. 35 (2), pp. 175-183. DOI: http:// dx.doi.org/10.1016/j.optmat.2012.07.024.

3. Bajer E. Modyfikatsya DNA dlya zastosowac $w$ optyce nieliniowej [Modification of DNA for Application in Nonlinear Optics. Master Thesis]. Cracow University of Technology, Poland, 2010.356 p.

4. Bakhracheva Yu.S. Fracture Toughness Prediction by Means of Indentation Test. International Journal for Computational Civil and Structural Engineering, 2013, vol. 9, no. 3, pp. 21-24.

5. Bakhracheva Yu.S. Operativnaya otsenka sklonnosti materialov k khrupkomu razrusheniyu pri staticheskom i tsiklicheskom nagruzhenii. Diss. kand. tekhn. nauk [Operative Estimation of Materials' Liability to Brittle Fracture Under Static and Cyclic Loading. Cand. techn. sci. diss.]. Velikiy Novgorod, NovGU Publ., 2004. 126 p.

6. Baron A.A, Bakhracheva Yu.S. A Method for Impact Strength Estimation. Mechanika, 2007, vol. 66, no. 4, pp. 31-35.

7. Baron A.A., Bakhracheva Yu.S., Osipenko A. Fracture Toughness Estimation by Means of Indentation Test. Mechanika, 2007, vol. 67, no. 5, pp. 33-36.

8. Baron A.A., Gevlich D.S., Bakhracheva Yu.S. Specific Plastic Strain Energy as a Measure of the Cracking Resistance of Structural Materials. Russian metallurgy (Metally), 2002, no. 6, pp. 587-592.

9. Berlin K., Jain R. K., Simon M. D., Richert C. A Porphyrin Embedded in DNA. J. Org. Chem., 1998, vol. 63, pp. 1527-1535.

10. Bouamaied I., Fendt L.-A., Hussinger D., Wiesner M., Thöni S., Amiot N., Stulz E. Nucleosides Nucleotides. Nucleic Acids, 2007, vol. 26, pp. 15331538.

11. Campbell W.M., Burrell A.K., Officer D.L., Jolley K.W. Porphyrins as Light Harvesters in the DyeSensitized TiO2 Solar Cell. Coord. Chem. Rev., 2004, vol. 248, pp. 1363 -379.

12. Campbell W.M., Jolley K.W., Wagner P., Wagner K., Walsh P. J., Gordon K.C., SchmidtMende L., Nazeeruddin M.K., Wang Q., Gratzel M., Officer D.L. Highly Efficient Porphyrin Sensitizers for Dye-Sensitized Solar Cells. J. Phys. Chem. C, 2007, vol. 111, pp. 11760-11762. 


\section{ТЕХНИКО-ТЕХНОЛОГИЧЕСКИЕ ИННОВАЦИИ}

13. Clausen-Schaumann H., Rief M., Tolksdorf C., Gaub H. Mechanical Stability of Single DNA Molecules. Biophys. Journal, 2000, vol. 78 (4), pp. 1997-2007. DOI: 10.1016/S0006-3495(00)76747-6.

14. Crick F.H.C., Watson J.D. The Complementary Structure of Deoxyribonucleic Acid. Proc. Royal Soc., 1954, vol. 223, pp. 80-96.

15. Derkowska B., Wojdyla M., Bala W., Jaworowicz K., Karpierz M., Grote J.G., Krupka O., Kajzar F., Sahraoui B. Influence of Different Peripheral Substituents on the Nonlinear Optical Properties of Cobalt Phthalocyanine Core. Journal of Applied Physics, 2007, vol. 101, (8), 083112(1-8).

16. Grote J. Biopolymer Materials Show Promise for Electronics and Photonics Applications. SPIE newsroom, 2008. DOI: 10.1117/2.1200805.1082.

17. Havinga E.E., Van Pelt P. Electrochromism of Organic Dyes in Polymer Matrices. Jennings B.R., ed. Electrochromism of Organic Dyes in Polymer Matrices. New York, Plenum Press, 1979, pp. 89-97.

18. Hayes R.A., Feenstra B.J. Video-Speed Electronic Paper Based on Electrowetting. Nature 425, 2003, pp. 383-385.

19. Hoshino Y., Nakayama H., Okahata Y.J. Preparations of a RNA-Lipid Complex Filmand Its Physical Properties. Nucleic Acids Res. Suppl., 2001, no. 1, pp. 61-62.

20. Hung Y-C., Lin Hsu W. T.-Y., Chiu Y.-W., Wang Y. -S. and Fruk L. Functional DNA Biopolymers and Nanocomposites for Optoelectronic Applications. Opt. Mat., 2012, vol. 34, pp. 1208-1213.

21. Ijiro K., Okahata Y. A DNA-Lipid Complex Soluble in Organic Solvents. J. Chem. Soc., Chem. Commun., 1992, vol. 18, pp. 1339-1341.

22. Kawabe Y., Wang L., Horinouchi S., Ogata N. Amplified Spontaneous Emission From Fluorescent Dye-Doped DNA-Surfactant Films. Adv. Mater., 2000, vol. 12, pp. 1281-1283.

23. Kawabe Y., Wang L., Koyama T., Horinouchi S., Ogata N. Light Amplification in Dye-Doped DNASurfactant Complex Films. Proc. SPIE, 2000, 4106, pp. 369-376.

24. Kimura H., Machida S., Hone K., Okahata Y. Effect of Lipid Molecules on Twisting Motions of DNA Helix Studied by Fluorescence Polarization Anisotropy. Polymer Journal, 1998, 30, pp. 708-712.

25. Koyama T., Kawabe Y., Ogata N. Electroluminescence as a Probe for Electrical and Optical Properties of Deoxyribonucleic Acid. Proc. SPIE, 2002, vol. 4464, pp. 248-255.

26. Large M.C.J., CrokeD.T., Blau W.J., McWilliam P., Kajzar F. EFISH in Electrolyte and Polyelectrolyte Systems. Mol. Cryst. Liq. Cryst,. Sc. \& Technol., Section B: Nonl. Opt., 1995, vol. 12 (3), pp. 225-238.

27. Large M.C.J., Croke D.T., Blau W.J., McWilliam P., Kajzar F. Molecular Length Dependent
Type Polarizability. Nonlinear Optical Properties of Organic Molecules IX, G. Mohlmann Ed. Proc. SPIE, 1996, vol. 2852, p. 36.

28. Mandelkern M., Elias J., Eden D., Crothers D. The Dimensions of DNA in Solution. Journal Mol. Biol., 1981, vol. 152 (1), pp. 153-161. DOI:10.1016/00222836(81)90099-1.

29. Manning G.S. The Molecular Theory of Polyelectrolyte Solutions With Applications to the Electrostatic Properties of Polynucleotides. Q. Rev. Biophys., 1978, vol. 11 (2), pp. 179-246.

30. Moreira L.M., dos Santos F.V., Lyon J.P., Maftoum-Costa M., Pacheco-Soares C., da Silva N.S. Photodynamic Therapy: Porphyrins and Phthalocyanines as Photosensitizers. Aust. J. Chem., 2008, vol. 61, pp. 741-754.

31. Niziol J., Sniechowski M., Hebda E., Jancia M., Pielichowski J. Properties of DNA Complexes With New Cationic Surfactants. Chem. Chem. Technol., 2011, vol. 5 (4), pp. 397-402.

32. Nogi M., Yano H. Transparent Nanocomposites Based on Cellulose Produced by Bacteria Offer Potential Innovation in the Electronics Device Industry. $A d v$. Mat., 2008, vol. 20, pp. 1849-1852.

33. Onoda A., Igarashi M., Naganawa S., Sasaki K., Ariyasu S., Yamamura T. Circular Dichroism of Neutral Zinc Porphyrin-Oligonucleotide Conjugates Modified with Flexible Linker._Bull. Chem. Soc. Jpn., 2009, 82, pp. 1280-1286.

34. Pawlik G., Mitus A. C., Myśliwiec J., Miniewicz A., Grote J.G. Photochromic Dye SemiIntercalation Into DNA-Based Polymeric Matrix: Computer Modelling and Experiment. Chem. Phys. Lett., 2010, vol. 484, pp. 321-323.

35. Pawlik G., Radosz W., Mitus A.C., Myњliwiec J., MiniewiczA., Kajzar F., Rau I., Grote J.G. Kinetics of Grating Inscription in DR1: DNA-CTMA Thin Film: Experiment and Semi-Intercalation Approach. Proc. SPIE, 2012, vol. 8464, pp. 18-25.

36. Pawlik G., Radosz W., Mitus A.C., Myśliwiec J., Miniewicz A., Kajzar F., Rau I. Grating Inscription in DR1: DNA-CTMA Thin Films: Theory and Experiment. Proc. SPIE, 2013, vol. 8817, pp. 15-20.

37. Pray L.A. Discovery of DNA Structure and Function: Watson and Crick. Nature Education, 2008, vol. 1 (1), pp. 16-18.

38. Rau I., Czaplicki R., Derkowska B., Grote J.G., Kajzar F., Krupka O., Sahraoui B. Nonlinear Optical Properties of Functionalized DNA-CTMA Complexes. Nonl. Opt. Quant. Opt., 2011, vol. 42, pp. 283-324.

39. Santa Lucia J. A Unified View of Polymer, Dumbbell, and Oligonucleotide DNA NearestNeighbor Thermodynamics. Proc. Natl. Acad. Sci. USA, 1998, vol. 95 (4), pp. 1460-1465. DOI:10.1073/ pnas.95.4.1460. PMID 9465037. 
40. Semenova L.M., Bakhracheva Yu.S., Semenov S.V. Laws of Formation of Diffusion Layers and Solution of the Diffusion Problem in TemperatureCycle Carbonitriding of Steel. Metal Science and Heat Treatment, 2013, vol. 55, no. 1-2, pp. 34-37.

41. Sergeyev V.G., Pyshkina O.A., Lezov A.V., Mel'nikov A.B., Ryumtsev E.I., Zezin A.B., Kabanov V.A. DNA Complexed with Oppositely Charged Amphiphile in Low-Polar Organic Solvents, Langmuir, 1999, vol. 15, pp. 4434-4440.

42. Shapochkin V.I., Semenova L.M., Bakhracheva Y.S., Gyulikhandanov E.L., Semenov S.V. Effect of Nitrogen Content on the Structure and Properties of Nitrocarburized Steel. Metal Science and Heat Treatment, 2011, vol. 52, no. 9-10, pp. 413-419.

43. Stephenson A.W.I., Bomholt N., Partridge A.C., Filichev V.V. Significantly Enhanced DNAThermal Stability Resulting from Porphyrin H-Aggregate Formation in the Minor Groove of the Duplex. Chem. Bio. Chem., 2010, vol. 11, pp. 1833-839. DOI: 10.1002/ cbic. 201000326.

44. Stephenson A.W. I., PartridgeA.C., Filichev V.V. Synthesis of b-Pyrrolic-Modified Porphyrins and Their Incorporation into DNA. Chem. Eur. J., 2011, vol. 17, pp. 6227-6238. DOI: 10.1002/chem.201003200.

45. Tanaka K., Okahata Y.J. A DNA-Lipid Complex in Organic Media and Formation of an Aligned Cast Film. J. Am. Chem. Soc., 1996, vol. 118 (44), pp. 10679-10683.

46. Trandafir V., Popescu G., Albu M.G., Iovu H., Georgescu M. Bioproduse pe baza de colagen. Editura Ars Docendi, Bucuresti, 2007. 356 p.

47. Uriarte-Montoyaa M. H., Arias-Moscosoa J.L., Plascencia-Jatomea M., Santacruz-Ortega H., RouzaudSández O., Cardenas-Lopez J.L., Marquez-Rios E., Ezquerra-Brauer J.M. Jumbo Squid (Dosidicus gigas) Mantle Collagen: Extraction, Characterization, and Potential Application in the Preparation of ChitosanCollagen Biolms. Bioresource Technology, 2010, vol. 101, pp. 4212-4219.

48. Vigneron J.P., Colomer J.F., Vigneron N., Lousse V. Natural Layer-by-Layer Photonic Structure in the Squamae of Hoplia Coerulea (Coleoptera). Phys. Rev. E, 2005, vol. 72, pp. 061904-061906.
49. Vizard D.L., White R.A., Ansevin A.T. Comparison of Theory to Experiment for DNA Thermal Denaturation. Nature, 1978, vol. 275, pp. 250-251.

50. Wang L., Fukushima M., Yoshida J., Ogata N. A Novel Photochromic Film Materials Derived From Supramolecules, DNA-Surfactant Complex: Spiropyran-DNA-CTMA Complex, Nanotechnology Toward Theorganic Photonics. GooTech Ltd., Chitose-shi, Japan, 2002, pp. 379-384.

51. Wang L., Ishihara K., Izumi H., Wada M., Zhang G., Ishikawa T., Watanabe A., Horinouchi S., Ogata N. Strongly Luminescent Rare-Earth Ion-Doped DNA-CTMA Complex Film and Fiber Materials. Proc. SPIE, 2002, vol. 4905, pp. 143-152.

52. Wang L., Liang Q., Wang Z., Xu J., Liu Y., Ma H. Preparation and Characterisation of Type I and V Collagens From the Skin of Amur Sturgeon (Acipenser Schrenckii). Food Chemistry, 2014, vol. 148, pp. 410-414.

53. Wang L., Yoshida J., Ogata N., Sasaki S., and Kajiyama T. Self-Assembled Supramolecular Films Derived From Marine Deoxyribonucleic Acid (DNA)Cationic Surfactant Complexes: Large-Scale Preparation and Optical and Thermal Properties. Chem. Mater., 2001, vol. 13 (4), pp. 1273-1281.

54. Wang L., Zhang G., Horinouchi S., Yoshida J., Ogata N. Optoelectronic Materials-Derived From Salmon Deoxyribonucleic Acid. Nonl. Opt., 2000, vol. 24, pp. 63-68.

55. Watanuki A., Yoshida J., Kobayashi S., Ikeda H., Ogata N. Optical and Photochromic Properties of Spiropyran-Doped Marine-Biopolymer DNA-Surfactant Complex Films. Proc. SPIE 5724, 2005, pp. 234-241.

56. Watson J.D., Crick F.H.C. Molecular Structure of Nucleic Acids. A Structure for Deoxyribose Nucleic Acid. Nature, 1953, vol. 171, pp. $737-738$.

57. Yoshida J., Wang L., Kobayashi S., Zhang G., Ikeda H., Ogata N. Optical Properties of PhotochromicCompound-Doped Marine-Biopolymer DNASurfactant Complex Films for Switching Applications. Proc. SPIE 5351, 2004, vol. 260. 


\section{НОВЫЕ ВОЗМОЖНОСТИ \\ ПРИМЕНЕНИЯ БИОПОЛИМЕРОВ В ФОТОНИКЕ}

\section{Рау Илеана}

$\mathrm{PhD}$, профессор,

факультет прикладной химии и материаловедения,

Политехнический университет, Бухарест

relatii.publice@upb.ro

ул. Полизу, 1-7, 011061 г. Бухарест, Румыния

\section{Кайзар Франсуа}

$\mathrm{PhD}$, профессор,

факультет прикладной химии и материаловедения,

Политехнический университет Бухареста

relatii.publice@upb.ro

ул. Полизу, 1-7, 011061 г. Бухарест, Румыния

Аннотация. В работе рассматриваются и обсуждаются возможности использования биополимеров, в частности дезоксирибонуклеиновой кислоты (ДНК) в фотонике. Пути их функционализации для получения желаемых свойств описаны и проиллюстрированы на нескольких примерах, в частности для обработки материалов в тонких пленках. При использовании спектроскопических методов следования показано проявление их фото-термической стабильности. В работе также рассматриваются физические свойства, и, в частности, линейные, нелинейные и фотолюминесцентные свойства полученных материалов.

Ключевые слова: дезоксирибонуклеиновая кислота, коллаген, линейные оптические свойства, фотолюминесценции, фото-термическая стабильность, оптический порог повреждения, тонкие пленки. 